\title{
MISSÕES ANTROPOLÓGICAS DE SÃO TOMÉ (1954) E ANGOLA (1955): CAMINHOS PARA A DESCOLONIZAÇÃO DA FOTOGRAFIA COLONIAL
}

\author{
Anthropological Missions of São Tomé (1954) and Angola (1955): \\ pathways to the decolonization of photography
}

Misiones Antropológicas de São Tomé (1954) y Angola (1955):

caminos para la descolonización de la fotografía

LORENA CHRISTINA BARROS TRAVASSOS ${ }^{\mathrm{I}^{*}}$

DOI: https://doi.org/10.1590/S2178-149420210105

\footnotetext{
'Universidade Nova de Lisboa, Faculdade de Ciências Sociais e Humanas, Instituto de Comunicação da NOVA, Projeto Photo Impulse - Lisboa, Portugal.

*Doutora em Ciências da Comunicação, Professora assistente convidada da Universidade Lusófona (lorenakrs@gmail.com). (D) https://orcid.org/0000-0001-6582-3233
}

Artigo recebido em 17 agosto de 2020 e aprovado para publicação em 11 novembro de 2020. 


\title{
RESUMO
}

Neste trabalho foram analisados dois conjuntos com fotografias inéditas produzidos durante as Missões Antropológicas em São Tomé e Príncipe (1954) e Angola (1955). A investigação, no âmbito do projeto Photo Impulse (financiado pela Fundação para a Ciência e a Tecnologia, Portugal), permitiu examinar o discurso presente em diários e documentos oficiais em conjunto com a fotografia e sua materialidade, que agrega sentidos ao discurso ao propor modos de exibição. Com a análise, buscou-se pensar sobre os caminhos possíveis para a descolonização da fotografia colonial por meio da reflexão sobre o poder investido ao arquivo e sobre as relações de gênero, que foram "esquecidas" pelo paradigma modernidade-colonialidade.

PALAVRAS-CHAVE: Fotografia Colonial; Missão Antropológica; Arquivo; Portugal; África; Descolonial.

\begin{abstract}
In this paper, two sets of unpublished photographs produced during the Anthropological Missions in São Tomé and Príncipe (1954) and Angola (1955) were analyzed. The investigation, in the scope of the Photo Impulse project (funded by Fundação para a Ciência e a Tecnologia, Portugal), allowed to examine the discourse present in official diaries and documents together with photography and its materiality, which adds meanings to the discourse when proposing views. With the analysis, we sought to reflect on the possible paths for the decolonization of colonial photography through the reflection of the power invested in the archive and the gender relations that were "forgotten" by the modernity-coloniality paradigm.
\end{abstract}

KEYWORDS: Colonial Photography; Anthropological Mission; Archive; Portugal; Africa; Decolonial.

\section{RESUMEN}

En este artículo se analizaron dos conjuntos de fotografías inéditas realizadas durante las Misiones Antropológicas en Santo Tomé y Príncipe (1954) y Angola (1955). La investigación, en el ámbito del proyecto Photo Impulse (financiado por la Fundación para la Ciencia y la Tecnología, Portugal), permitió examinar el discurso presente en los diarios y documentos oficiales junto con la fotografía y su materialidad, que agrega significados al discurso al proponer miradas. Con el análisis se buscó reflexionar sobre los posibles caminos para la descolonización de la fotografía colonial a través del reflejo del poder invertido en el archivo y las relaciones de género que fueron "olvidadas" por el paradigma modernidad-colonialidad.

PALABRAS CLAVE: Fotografía Colonial; Misión Antropológica; Dictadura; Portugal; África, Decolonial. 


\section{INTRODUÇÃO}

A fotografia é contemporânea da antropologia. Vista como imagem objetiva, que eliantropologia na medida em que a "busca antropológica recorrente pela diferença coincide exatamente com o truque que a fotografia encena na procura de seu 'efeito realidade'" (Pinney, 1992: 74). A partir do fim do século XIX, segundo Elizabeth Edwards (1990), a imagem fotográfica passou a fazer parte dos estudos antropológicos de forma mais organizada e sistêmica, vindo a ser um modo privilegiado de representação visual.

Edwards (2002) defendeu que não se pode falar de sentido e discurso quando se ignora a materialidade objectual da fotografia (objecthood). Está claro que a visualidade deve ser encarada como uma dimensão importante da vida e dos processos sociais, entretanto a consideração dos aspectos materiais das fotografias pode determinar sentidos que se integram ao discurso do produtor da imagem. No caso específico da fotografia das missões antropológicas, também os sentidos do colonialismo e do fascismo ditatorial português estão inclusos nos registos das missões científicas e nos seus aspectos materiais, afinal estes são objetos palpáveis que concebem a afirmação do poder sobre outros povos.

A importância da fotografia enquanto ferramenta para a antropologia física pode ser constatada na vasta produção realizada nas missões científicas coloniais portuguesas: rolos fotográficos, provas, negativos de vidro e acetato, além de um grande número de álbuns fotográficos produzidos em grande quantidade e em todas as missões. Essas imagens eram utilizadas como provas de superioridade racial em artigos científicos ou apresentações das investigações (com projeções luminosas ou não). Decerto, algumas também serviram para ilustrar cartões postais de exposições, mostrando assim o seu caráter dúbio.

Este artigo tem três partes interconectadas para propor caminhos para a descolonização da fotografia colonial. A primeira expõe as ideologias e objetivos das missões científicas portuguesas e dos cientistas em Portugal no século XX, com o surgimento da "Escola do Porto" e a utilização da antropologia física. A segunda apresenta uma análise descritiva dos dois conjuntos fotográficos produzidos na Missão Antropobiológica de Angola (MAA) (1955) e na Missão Científica de São Tomé e Príncipe (MSTP) — Secção Etnográfica (1954)'. Foram utilizados, como apoio dessa análise, os artigos científicos de Almeida e o diário pessoal do assistente para a compreensão dos sentidos das imagens produzidas pelo ponto de vista português, bem como para a observação da materialidade das fotografias.

Na terceira e última parte deste artigo, após a análise das imagens produzidas nas missões, são lançados caminhos possíveis para a descolonização das fotografias examinadas, 
que fazem parte de arquivos coloniais. Visto que se trata de uma questão complexa, esse caminho foi trilhado utilizando como bússola os estudos anti-imperiais e descoloniais que permitiram a reflexão acerca da colonialidade como continuação do colonialismo e das relações de gênero que foram negligenciadas pelo paradigma modernidade-colonialidade.

\section{As Missões ANTROPOLÓGICAS DE ANGOLA (1955) E SÃO TOMÉ E PRÍNCIPE (1954): CONTEXTO E HISTÓRIA}

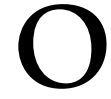
desenvolvimento da Antropologia Colonial em Portugal foi resultado do esforço de Mendes Correia (1888-1960). Com poder de interferência na política portuguesa, recebeu lugar de destaque na escola ao se tornar professor e diretor do Instituto de Antropologia da Universidade do Porto. As missões antropológicas surgem com a sua iniciativa, ao exaltar os ânimos de seus colegas para um renascimento imperial. Foi na sessão de encerramento do I Congresso Colonial do Porto, em 1934, que ele propôs um programa aos seus colegas cientistas para a investigação dos "indígenas" sob uma perspectiva antropológica, psicológica e linguística (Pereira, 2005). A Exposição Colonial, que acontecia ao mesmo tempo contando com objetos, fotografias e cenários que refaziam as moradas africanas com seus mais de 300 "exemplares" de nativos, servia para mostrar aos europeus — público em geral da exposição e cientistas - como a Antropologia Física seria valiosa quando aplicada nos territórios ultramarinos, ao permitir uma colonização mais racional que indicaria caminhos para a revalorização do trabalho indígena.

As missões científicas tiveram início na década de 1930 e foram desenvolvidas no contexto do período do Estado Novo (1933-1974), regime fascista de direita liderado por António Oliveira Salazar, por meio da Junta das Missões Geográficas e de Investigações Coloniais. Criado em 1936, esse órgão tinha as funções de desempenhar investigação, coordenação e consulta de materiais dos territórios coloniais, especialmente nas áreas de geografia, geodesia, hidrografia, astronomia, meteorologia, assuntos diplomáticos e de fronteiras (Poloni, 2011). Grande parte das missões só pôde ser realizada após a reforma da Junta das Missões em 1945 e passou a ter o caráter descritivo e classificatório das populações das colônias para desenvolver lucro para a metrópole, com base no estudo da força de trabalho dos africanos. As colônias serviam apenas para extração e o enriquecimento de Portugal.

0 médico António Mendes Correia, líder da Escola do Porto, era doutorado em Antropologia Física, tinha identificação com os estudos eugênicos e acreditava na superioridade da raça branca. Por isso, queria também provar que os portugueses possuíam uma "superioridade racial" em relação às pessoas de cor. 0 contexto colonialista, por isso, não está à parte das 
Missões Antropológicas; pelo contrário, comanda a ciência portuguesa e emerge enquanto prática situada num mesmo tempo e espaço (Roque, 2014). 0 mesmo vale para os cientistas que chefiaram essas missões: suas preferências, políticas e interesses profissionais determinaram a ciência produzida nas missões antropológicas durante o regime ditatorial português (Poloni, 2011). É evidente que não houve separação entre o Estado Novo e a ciência nas Missões. 0 chefe de Estado e os cientistas acreditavam, juntos, na exploração e eliminação dos corpos examinados em suas colônias.

Entre as missões realizadas na África, apresento algumas características da MAA em 1955 e da MSTP (Secção Etnográfica) realizada em 1954. As duas incursões foram chefiadas por António de Almeida (1900-1984) e tiveram como fotógrafo o auxiliar de antropometria António de Almeida Júnior.

A MAA foi chefiada por António de Almeida, também professor da Escola Superior Colonial. Almeida foi professor, antropólogo e político português. Formado em Medicina, fez pós-graduação na Escola de Medicina Tropical e na Escola Superior Colonial. A partir de 1935, lecionou Etnologia e Etnografia Colonial nesta última escola e assumiu a direção do Centro de Estudos de Etnologia do Ultramar. Graças ao seu assistente, António Marques de Almeida Júnior, a narrativa dos encontros com os africanos "observados" pôde ser analisada por meio dos seus diários pessoais, que descreviam algumas atividades de campo. Os documentos das missões também foram preservados e estão no acervo do Arquivo Histórico Ultramarino (AHU) em Lisboa. Apesar de os diários de campo do assistente possuírem cunho mais pessoal, foi possível extrair informações valiosas sobre o desenvolvimento das pesquisas nas colônias portuguesas. Também as fichas antropométricas foram preenchidas por Almeida Júnior, localizando as provas fotográficas de acordo com os respectivos rolos fotográficos.

No que se refere à MAA, olharemos especificamente para o conjunto de imagens coloridas produzidas em 1955 na zona de Oncócua, província de Cunene. Essas imagens são do último ano das missões antropobiológicas nesse país (que se deram em 1950, 1952 e 1955). As mesmas pessoas foram retratadas também em preto e branco para serem postas em fichas antropométricas (Figura 1A), o que indica que o fotógrafo estava sempre com duas câmaras, no mínimo, em suas incursões (Figuras 1A e 1B). Entretanto, serão analisadas apenas as imagens coloridas e que foram postas em caixilhos, ou seja, foram utilizadas para a projeção com luz a um público específico e restrito.

Os estudos conduzidos pela MAA procuravam recolher dados relacionados à rentabilização da mão de obra nativa. Almeida, chefe da missão, era fundamentalmente um antropólogo com interesse primordial em realizar medições antropobiológicas em grupos indígenas locais. Seguindo as regras ditadas por Mendes Correia, foram analisados "ca- 

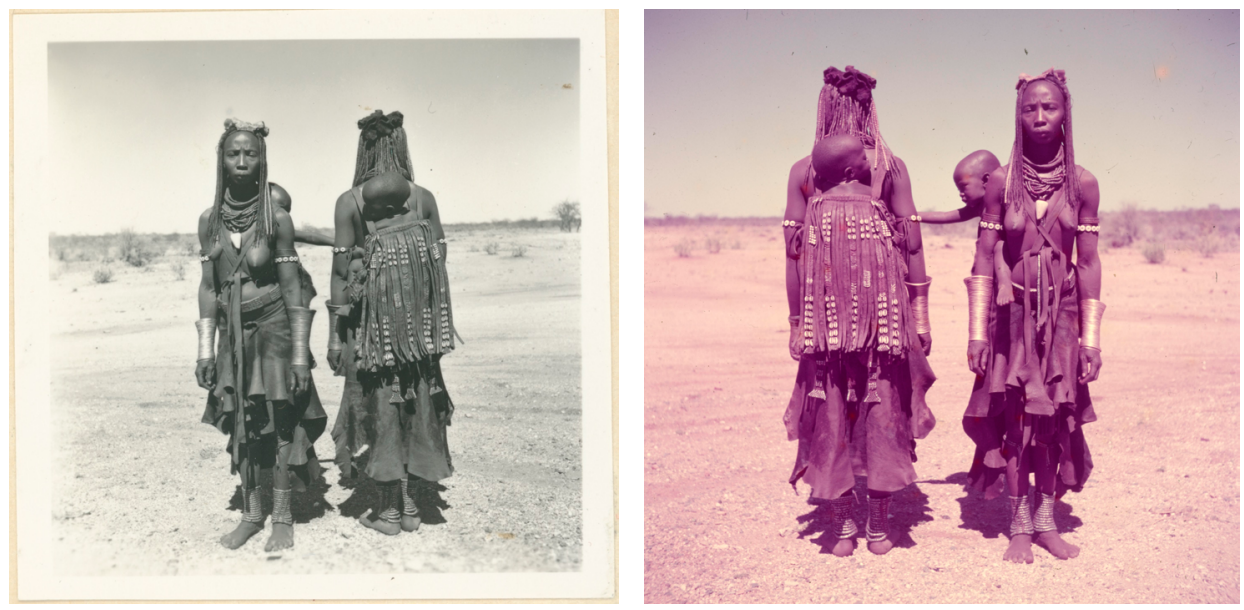

Figura 1 (A, B) - Fotografias realizadas em preto e branco e a cores em Angola, na Missão Antropobiológica de 1955, em Oncócua.

Fonte: Universidade de Lisboa/Instituto de Investigação Científica Tropical.

racteres descritivos, caracteres antropométricos, grupos sanguíneos, metabolismo basal, alguns caracteres fisiológicos e psicológicos" (Correia, 1934: 15). Um indivíduo analisado apresentava-se, nessa pesquisa, como representante de todo o seu grupo étnico, perpetuando a generalização de povos por intermédio da criação de "tipos". Ao fim, a inventariação de tipos produzia, com o auxílio da câmara fotográfica, uma identificação geral e generalizante de capacidades físicas, mentais e psicológicas de indígenas que, além de tudo, não tinham seus nomes nas fichas antropométricas, sendo representados apenas por etnia e gênero (Figuras 2A e 2B).

Essa missão teve início em 30 de agosto de 1955 e terminou no início de janeiro do ano de 1956. Segundo o diário do assistente, foram cerca de 260 "observações" apenas no mês de dezembro de 1955, o que ilustra a grandeza da missão e também a dimensão da produção fotográfica naquele período. Na Estudos Ultramarinos - Revista do Instituto Superior de Estudos Ultramarinos, publicada em 1956, foram apresentados os resultados da MAA:

A $3^{a}$ Campanha científica realizada pela Missão Antropobiológica de Angola, chefiada pelo Prof. Dr. António de Almeida, foi muito frutuosa pois, a par do estudo das populações mais primitivas da Província - Mucuíssis e Mútuas, povos de língua hotentote (Hotentotes propriamente ditos, Mucuépes, Muquédes e Cazamas ou Cacuengos) e Bosquimanos (Mucuancalas e Cassequéles) - , descobriu muitas estações pré-históricas, examinou importantes pinturas e gravuras rupestres e alguns recintos muralhados [...]. 


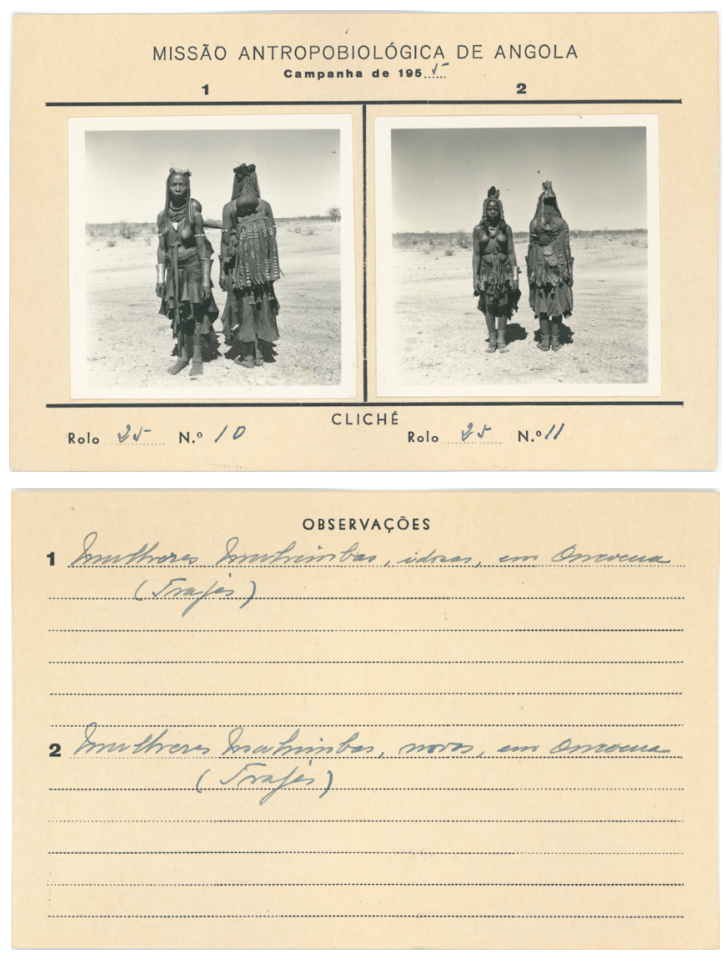

Figura $2(A, B)$ - Ficha antropométrica com informação sobre a imagem de mulheres Muhimbas (idosas e novas) observadas em Oncócua, Angola, 1955. Fonte: Universidade de Lisboa/Instituto de Investigação Científica Tropical.

Entre os resultados citados por António de Almeida na mesma revista, em 1956, faz-se referência ao estudo antropobiológico dos Mucuanhocas, etnia do grupo representado nas imagens que serão analisadas neste artigo. Segundo o chefe da missão, trata-se de uma "tribo negra de Carvalhão (deserto de Moçâmedes) e de Oncócua" a respeito da qual, naquele momento, foram realizados alguns levantamentos, como: "Anotações etnológicas — vida familiar e social, mutilações étnicas, tipos de alimentação etc. Colheita de impressões digitais. Determinação dos grupos sanguíneos ABO e Rh. Gravação de algumas músicas" (Estudos Ultramarinos..., 1956).

Em seu diário pessoal, o assistente Almeida Júnior relatou o momento exato da produção do conjunto fotográfico colorido, embora seu relato não tenha grandes detalhes. No dia 7 de outubro de 1955, ele escreveu: "De manhã fui ao Carvalhão levar gente e tirei lá algumas fotografias coloridas. De tarde tornamos lá e depois seguimos até S. João do Sul, tendo tirado algumas fotografias ao cemitério de pretos-cristãos e feiticista". As suas anotações são bastante resumidas, não trazendo mais detalhes sobre as fotografias coloridas realizadas, ou seja, 

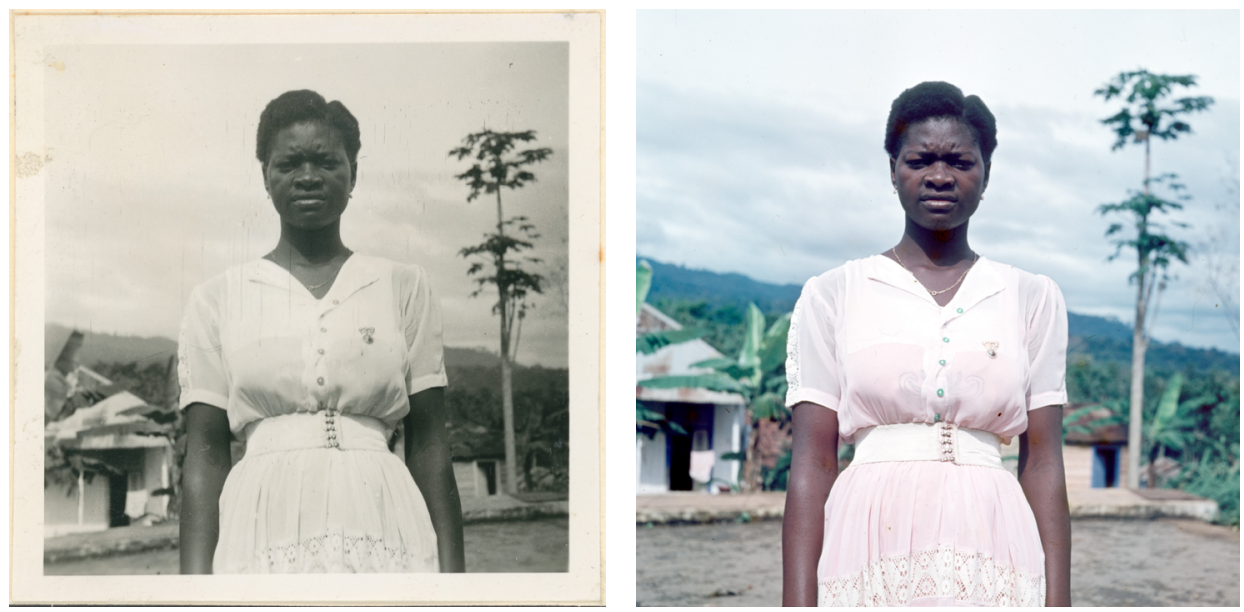

Figura 3 (A, B) - Fotografias em preto e branco e a cores realizadas em São Tomé, 1954. Fonte: Universidade de Lisboa/Instituto de Investigação Científica Tropical.

sem qualquer menção à relevância dessas fotos ou mesmo ao motivo de serem produzidas utilizando rolos coloridos Kodachrome (Figuras 3A e 3B).

A MSTP, segundo ofício endereçado ao diretor-geral do Tribunal de Contas de Lisboa, de $n^{0} 1.061 / 54$, de 12 de janeiro do mesmo ano, foi criada por portaria em 13 de agosto de 1954, com a finalidade principal de obter "elementos" nas ilhas de São Tomé e Príncipe para "elaboração de estudos a apresentar na Conferência Internacional dos Africanistas Ocidentais", que aconteceria na mesma localidade e no ano seguinte. Ainda segundo esse ofício, o tempo seco e menos quente era o melhor momento para essa pesquisa, por causa das chuvas intensas que alcançavam as ilhas entre os meses de setembro e abril. Em razão dos trâmites burocráticos portugueses, em 3 de setembro de 1954 partiram no paquete "Angola" António de Almeida e seu assistente Almeida Júnior na secção etnográfica.

Com tamanho modesto, a MSTP durou quase três meses, entre 14 de setembro e 29 de novembro de 1954. Resultou ao final em 215 observações "só com as medidas necessárias para os índices de robustez e observações dos caracteres descritivos e fisiológicos" (Almeida Júnior, 1954, Diário de campo - Arquivo Histórico Ultramarino). A MAA apresentou mais observações em um mês de investigação do que toda a MSTP (foram 260 observações no mês de dezembro de 1955 em Angola). 0 assistente da missão, em seu diário pessoal, relatou ainda que parte dos indivíduos analisados, classificados como "forros", tiveram "observações reduzidas", pois "é tal a percentagem de mestiçagem que não valerá a pena fazer-se o seu estudo" (Almeida Júnior, 1954, Diário de campo - 
Arquivo Histórico Ultramarino). Essa mestiçagem parece ter causado desânimo no assistente da investigação, visto que o diário escrito em São Tomé resultou em pouquíssimas linhas que refletem, em grande parte, os "problemas" decorrentes da grande mestiçagem dos corpos analisados e da dificuldade de encontrar os trabalhadores nas roças para a investigação ${ }^{2}$. Não há menção, no diário de Almeida Júnior em São Tomé, à produção de imagens coloridas e, por isso, não foi possível compreender a escolha desse conjunto para revelação a cores. No entanto, como na MAA, nota-se que foram utilizadas duas câmaras para a produção de imagens do mesmo fotografado.

Nas missões antropológicas analisadas, os estudos científicos seguiam interesses pessoais dos investigadores e serviram para, além do estabelecimento de caracteres físicos e psicológicos generalizantes de etnias, abastecer a produção de conteúdos "científicos" sobre as colônias africanas sob o ponto de vista europeu e racial, sem levar em consideração critérios culturais que já eram apreciados pelos estudos antropológicos em outros países da Europa. Nesse sentido, as investigações da força física e da adaptabilidade daquele povo, durante as missões, serviram para legitimar cientificamente a exploração de trabalho e das terras das colônias e a ideologia colonial/fascista da época ditatorial portuguesa, visto que as colônias deveriam produzir lucros para a metrópole e nunca o desenvolvimento de seus territórios.

\section{AS FOTOGRAFIAS DAS MISSÕES DE ANGOLA E SÃO TOMÉ: CARACTERÍSTICAS E IMPRESSÕES}

W as missões científicas portuguesas a imagem fotográfica era determinante para as Na MAA (1955) e na MSTP (1954), o grande volume de fotografias inéditas presentes em rolos fotográficos, provas impressas, cartões descritivos e slides ilustra essa importância.

0 material fotográfico estava presente no material técnico para a realização de trabaIhos científicos nas "colônias" — junto com estojos antropométricos e escalas para a cor dos cabelos, olhos e pele — , sendo mais utilizado no âmbito da antropologia física e dos estudos antropométricos. Entretanto, também permitiu retratar outros elementos que eram importantes para essas missões, como os trajes (roupas e adereços), contextos locais (sepulturas), a identificação de plantas, atividades econômicas, escarificações e tatuagens, além do patrimônio edificado pelos colonizadores (igrejas, fortes, pontes etc.) e do material arqueológico encontrado na região.

A técnica nos retratos da antropologia física é a mesma utilizada em retratos criminais, seguindo os preceitos da bertillonage, ou seja, os retratos produzidos apresentavam 
os indígenas de frente e de perfil, o que servia para visualizar os traços fisionômicos. Essa representação de "tipos" humanos permitiu isolar características físicas para atribuir aspectos de temperamento generalizantes que eram correspondentes à largura de nariz ou boca, entre outros traços fisionômicos. Esse processo homogeneizante de identidades, essência da antropologia física, pretendia mostrar que era possível "ler" o outro por meio de suas características físicas. Os indivíduos analisados, desgarrados de suas próprias individualidades, eram sujeitados "ao escrutínio, forçados a emitir sinais, porém alijados do controle de significado [...]" (Tagg, 2005: 20), pois a interpretação das imagens ficava a cargo dos interesses dos cientistas e da ideologia dominante.

Funcionando como ferramenta perfeita para o arquivamento e documentação de fisionomias encontradas nas colônias, a fotografia foi produzida em grande volume para que pudesse gerar um grande arquivo de "tipos" e, assim, controlar os povos colonizados. Esse olhar positivista permitiu, além de atribuição de generalizações ao corpo examinado, a determinação do que seria considerado como "anormalidade" aos olhos dos cientistas europeus ao mirar o corpo do Outro. Por esse motivo, as coleções fotográficas produzidas no contexto das missões surgiram como prática de representação de modalidade discursiva que proporciona legitimação, exercício e manutenção dos poderes coloniais (Hall, 1996). Foi esse poder colonial que permitiu moldar por muito tempo imaginários acerca dos territórios e das pessoas, com o intuito de reforçar a presença da suposta superioridade do europeu sem que os fotografados, humilhados e inferiorizados, pudessem ou tivessem direito de opinar (Figuras 4A e 4B).

0 poder exercido com o uso das fotografias no colonialismo foi tão intenso que foi possível, por meio da câmara, determinar a "raça" inferior, que seria mais próxima de um animal do que de um humano. Em Raças do Império, Mendes Correia definiu "raça" como elemento diferenciador e classificatório, que determina "diferenças de costumes, de organizações sociais, de tendências psicológicas" (Correia, 1943: 22). A "diferença", para Correia, nunca foi algo positivo, mas sim degenerativo e deveria ser intensamente combatida. Contaminado pelo racismo, ele defendia uma unidade rácica e cultural do povo português como argumento contra a mistura de "raças", pois muito facilmente se poderia desfigurar a "fisionomia tradicional da pátria" (Correia, 1940: 23) caso se aceitasse o mestiçamento (Figuras 5A e 5B).

Contraditoriamente, a política de povoação das colônias comandada pela metrópole estava diretamente conectada à mestiçagem. Correia, para não contrariar as ordens superiores, passou a considerar que "em 'regiões onde a mulher branca esteja ausente', o mestiçamento é 'inevitável e fatal' e reconhece a existência de mestiços ilustres, contudo, desaconselha 'o mestiçamento como regra' em todo o império" (Matos, 2014: 60). As mulheres que viviam nas colô- 

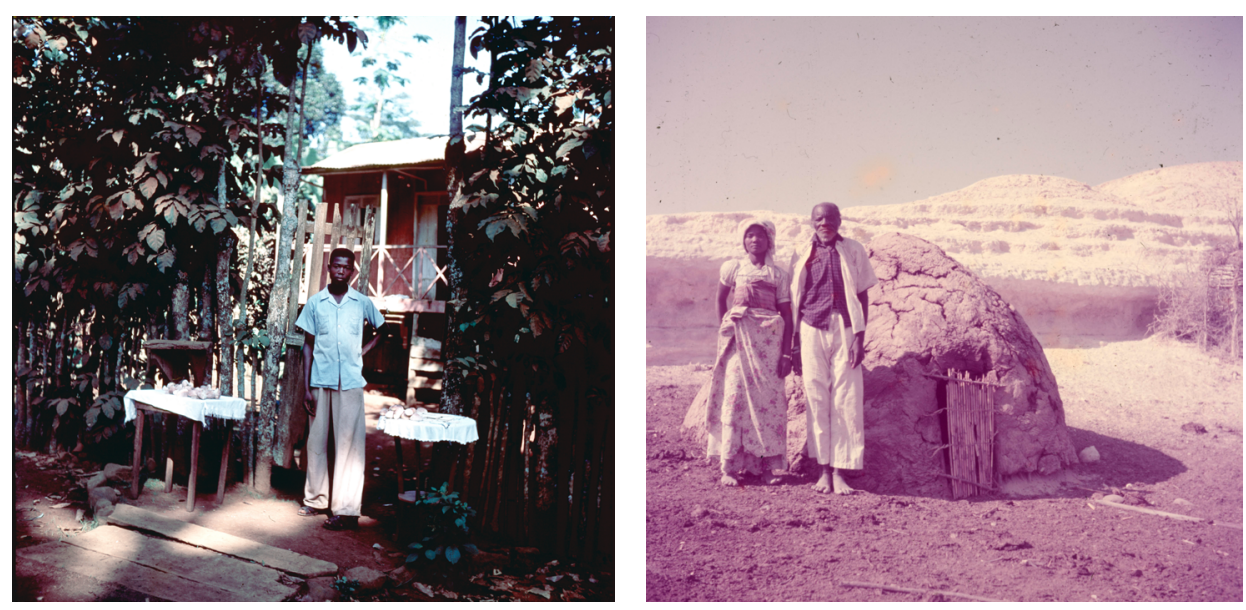

Figura 4 (A, B) - Fotografias coloridas em São Tomé, 1954 (1) e Angola, 1955 (2). Fonte: Universidade de Lisboa/Instituto de Investigação Científica Tropical.
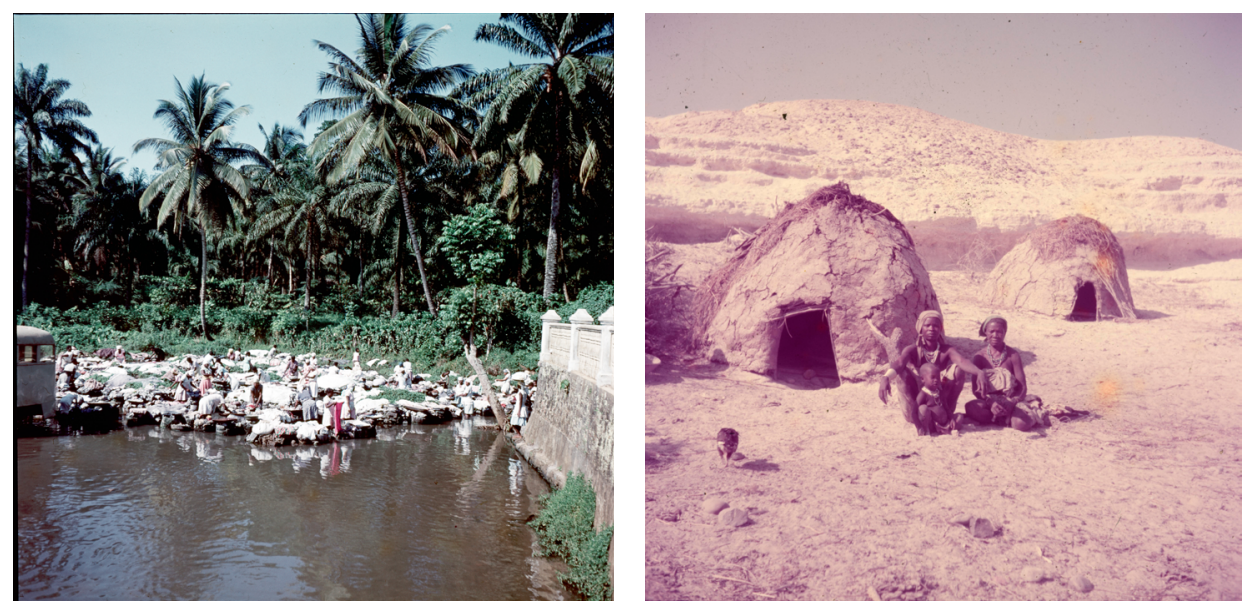

Figura 5 (A, B) - Fotografias em São Tomé (Lavadeiras), 1954; e Angola (Samba em Oncócua), 1955. Fonte: Universidade de Lisboa/Instituto de Investigação Científica Tropical.

nias tornaram-se, com a ajuda do Estado, um grande atrativo para a emigração de aventureiros da metrópole, pois assim poderiam aumentar a quantidade de escravos-mestiços, mesmo que à base de violência contra a mulher. 0 mestiço só poderia ser gerado, por isso, fora dos limites do território português e para produzir lucros para o Estado português.

Os aspectos materiais dos conjuntos fotográficos analisados são importantes para esta análise, pois o contexto funcional do material não deve ser visto como suporte neutro: ele dialoga com a própria imagem na produção de sentidos (Edwards, 2002). As imagens, enquanto 
objetos, são produzidas e armazenadas por razões específicas e podem ser, também, cortadas ou alteradas na sua forma de exibição, pois a visualização implica fator(es) físico(s) de interação com os materiais. As características do material fotográfico produzem um impacto na maneira de "ler", pois impõem expectativas e padrões de uso. Por isso, os aspectos técnicos e físicos das imagens coloniais raramente são aleatórios, mesmo que não estejam totalmente articulados (Edwards, 2002: 68).

Neste caso, as fotografias coloridas que foram produzidas na Missão Científica de São Tomé (20 fotos) e na Missão Antropobiológica de Angola (21 fotos) possuem algumas características que se conectam ao discurso de seus produtores, proporcionando leituras de intenção da investigação antropológica portuguesa. Apesar de serem produzidos em datas e localidades diferentes, há características comuns aos dois conjuntos:

- a utilização da cor (com filmes Kodachrome em Angola e Fujifilm em São Tomé e Príncipe);

- as imagens foram postas em caixilhos para que fossem projetadas com fontes de luz.

0 que é curioso é que algumas dessas imagens foram encontradas também em preto e branco, ou seja, foram produzidas em duas câmaras distintas no mesmo momento, mas as coloridas foram escolhidas para a apresentação via projeção de luz (Figuras 6A e 6B).

Edwards (2002) defende que a materialidade está intimamente relacionada à biografia social que, por sua vez, surge em duas formas. A primeira refere-se ao conteúdo da imagem,
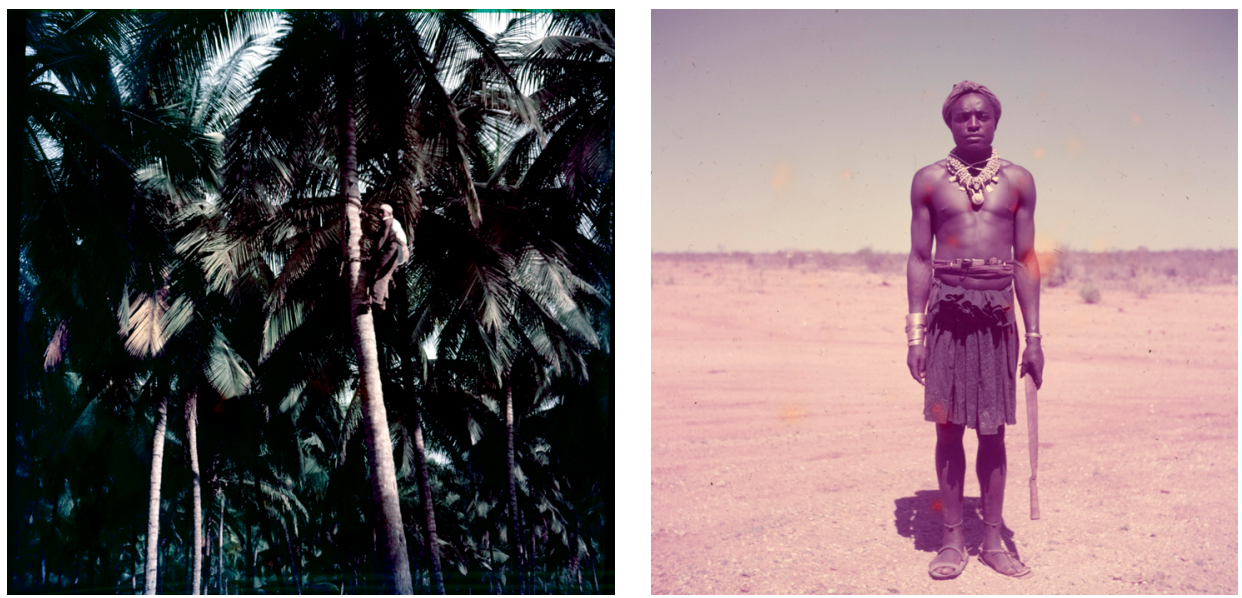

Figura 6 (A, B) - Fotografias de homem (tira cocos) em São Tomé (1954) e homem em Angola (1955). Fonte: Universidade de Lisboa/Instituto de Investigação Científica Tropical. 
como impressões diferentes, formatos de publicação ou slides de lanterna, entre outras, que envolvem modificações na forma de visualização da fotografia original. A segunda forma diz respeito à fotografia como um objeto socialmente saliente que se move no espaço e no tempo (Edwards, 2002: 68). No caso específico deste estudo, as fotografias estão em arquivo público e foram modificadas em seu conteúdo para a visualização pela projeção de luz restrita a um grupo composto por investigadores portugueses, seguidores e professores da Escola do Porto e de um Estado ditatorial.

Patrícia Ferraz de Matos aponta que

as fotografias, e também as "projecções luminosas", eram utilizadas com alguma frequência nas conferências proferidas na [Sociedade Portuguesa de Antropologia e Etnologia] SPAE (sociedade da qual [Mendes Correia] foi fundador em 1918 e presidente a partir de 1929) pelos seus sócios. (Matos, 2014: 49).

Essas imagens projetadas e ampliadas na parede ou superfície antecederam o cinema, mas surgiram como mais uma forma de observar o corpo do Outro com seus detalhes ampliados no campo da antropologia física.

Os aspectos técnicos e físicos das imagens coloniais que estudamos, na falta de elementos que os justifiquem, não são vistos como aleatórios. A falta de informação parece alimentar ainda mais um contexto secreto ou fetichista dos corpos fotografados. 0 contexto de produção das fotografias não deixa espaço para a compreensão de uma produção desinteressada e aleatória das imagens. Sabemos, entretanto, que elas existem e que foram produzidas, selecionadas e apresentadas a um grupo seleto das missões antropológicas, pois estão organizadas com suas informações na caixa original dos slides que está guardada no AHU. São conjuntos de objetos que foram separados daqueles que retrataram (Poole, 1997 apud Edwards, 2002: 71), reproduzindo "tipos" em vez de indivíduos. Na visualização de slides, a resposta é privada e concentrada em um único grupo de indivíduos (Figuras 7A, 7B, 7C e 7D).

A utilização da cor, também aspecto da materialidade fotográfica, une os dois conjuntos analisados, pois ela exprime uma aproximação do objeto fotografado com a realidade 3 . É o contrário do que ocorre com as imagens preto e branco produzidas e coladas em cartões antropométricos, que afastam da realidade com o estranhamento das pessoas analisadas 4 . Entretanto, neste caso, por falta de informações complementares nos diários de campo do fotógrafo, a utilização da cor apenas parece ser adotada como uma forma de representar aquela realidade exótica de modo a realçar as cores de pele e das localidades fotografadas, fornecendo uma outra dimensão, mais plástica e mais próxima da vida nas missões. Junto com 

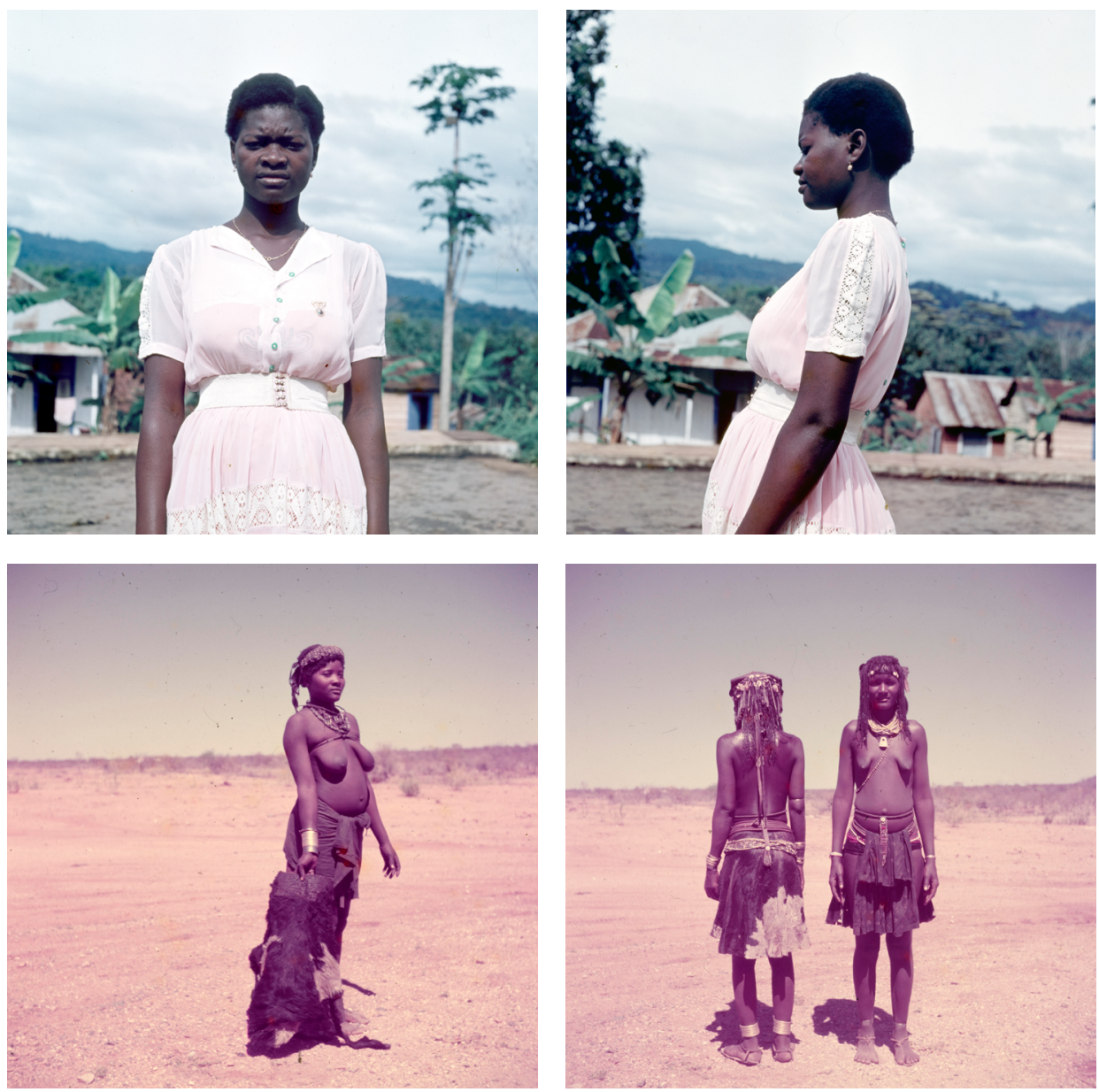

Figura 7 ( $A, B, C, D)$ - Mulher vestida "à moda europeia" em São Tomé, 1954. Mulher Mukuanhoca e mulheres Muhimba em Angola, 1955.

Fonte: Universidade de Lisboa/Instituto de Investigação Científica Tropical.

a projeção das imagens, com a ampliação de partes ou de todo o corpo, os povos fotografados ganham uma dimensão mais "real".

Os temas abordados nos dois grupos fotográficos podem ser resumidos por: construções, trajes, natureza, atividades econômicas e "tipos" nas tradicionais poses de frente e perfil. Os "tipos", por vezes disfarçados de "trajes", são sobretudo imagens de mulheres em todas as posições solicitadas pela Antropologia Física, enquanto os homens foram fotografados apenas frontalmente. É preciso ressaltar que o "esquema fotográfico" das imagens coloridas analisadas tem especificidades próprias que diferem do das demais, realizadas em 
preto e branco durante o mesmo período. Em termos quantitativos, podemos dizer que, no grupo fotográfico de Angola, das 21 fotografias, nove apresentaram mulheres e apenas duas são de homens. No grupo fotográfico de São Tomé, composto por 20 fotografias, sete são de mulheres de frente e perfil e três são de homens fotografados apenas de frente e, muitas vezes, distantes do fotógrafo. Fica claro, assim, a preferência por fotografar mulheres e seus corpos pelo grupo de investigadores.

0 único aspecto em que difere o conteúdo dos dois conjuntos de imagens parece ser a representação da presença de "sinais de civilização" ou daqueles aspectos advindos da colonização, declarados tanto nas vestimentas como no que se apresenta no entorno dos fotografados. As pessoas retratadas em Angola estão em seus trajes tradicionais e em um deserto, com seus modos de vida próprios, entretanto a prova da chegada da "civilização" surge nas imagens de um cemitério "cristão" no deserto de Moçâmedes. Nesse cemitério, cruzes católicas demarcam o lugar dos mortos no chão para representar a evangelização forçada dos angolanos (Figuras 8A, 8B e 8C).

Por outro lado, as imagens da Missão Científica de São Tomé e Príncipe mostram a presença dos modos e vestimentas muito próximos àqueles da vida portuguesa. Podem ser visualizadas as "marcas de civilização" nas ruas calçadas, carros, prédios com o estilo português e também na própria vestimenta do povo local. Há três imagens que mostram ruas com calçamento, cidade com arquitetura similar à da metrópole e, claro, uma grande igreja para a conversão daquele povo e refúgio dos portugueses (Figuras 9A, 9B e 9C). Servem, essas construções, para mostrar o patrimônio que foi erguido pelo império português na colônia com o trabalho forçado do nativo. São elas provas da força militar colonial exercida sobre um povo ao impor-lhes padrões morais e culturais.

Um fator histórico importante e que deve ser mencionado refere-se às diferenças de exploração colonial das duas localidades. Angola abasteceu durante muito tempo o mercado marítimo de escravos, fora e dentro da África, realizado por Portugal com a ajuda e bênção
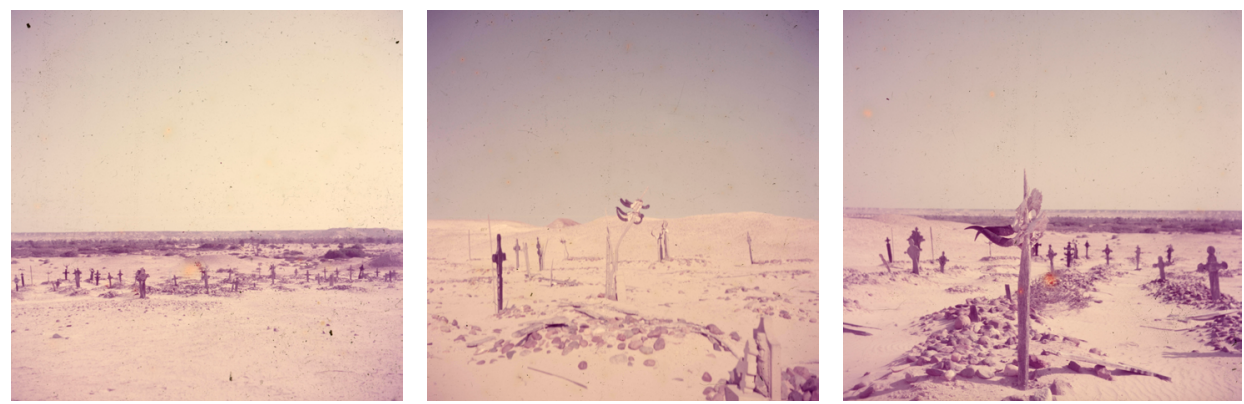

Figura $8(A, B, C)$ - Fotografias do "Cemitério de Pretos Cristãos em São João do Sul" Angola, 1955. Fonte: Universidade de Lisboa/Instituto de Investigação Científica Tropical. 

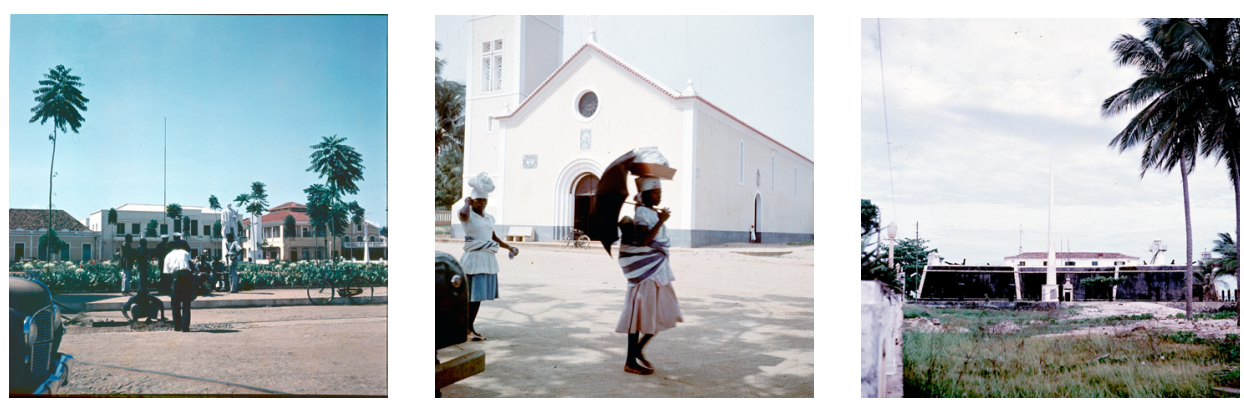

Figura 9 (A, B, C) - Fotografias mostram a colonização portuguesa em São Tomé, 1954. Fonte: Universidade de Lisboa/Instituto de Investigação Científica Tropical.

da Igreja. Já na segunda colonização de São Tomé e Príncipe, no século XIX, ainda existia a utilização da mão de obra escrava que vinha de Angola (e de outras colônias) para abastecer o sistema de plantation, baseado no regime de contrato, monocultura do cacau e dominância dos portugueses (Seibert, 2015). São Tomé e Príncipe era, de acordo com Pinto Andrade (1997 apud Berthet, 2012: 26), uma "colônia de plantação", local principal de fornecimento do cacau e do café e de grandes lucros para a metrópole. Essa diferença reflete-se nas fotografias das missões. 0 grupo delas produzido em Angola mostra corpos fortes, altivos, mulheres férteis com crianças, para refletir aquela "colônia de escravos" que tanto serviu como fonte de força física para a metrópole. 0 segundo grupo, produzido em São Tomé, mostra já uma cidade climatizada com os costumes portugueses e altamente miscigenada, refletindo a finalidade daquele local enquanto "colônia de plantação", com portugueses nos comandos das "roças" e com contratados que recebiam salários irrisórios, em condições análogas às da escravidão.

A produção intensa de visualidade — com a produção de fotografias e coleta de artefactos — foi amplamente utilizada como alicerce de imaginários colonialistas. A sexualização do corpo da mulher nas fotografias das investigações científicas e a representação do "atraso" dos territórios explorados conforme parâmetros europeus não foram esquecidos nas fotografias das missões: serviam para mostrar o poder dos homens do Estado que tinham como "vocação" o salvamento daquelas pessoas ao levar-lhes os avanços da civilização. Trata-se de uma representação do "paradigma de salvamento" presente na fotografia antropológica descrita por Pinney (1997: 45).

Para compreender as camadas de discriminação e exploração do período colonial será preciso utilizar lentes que nos permitam compreender como a colonialidade (do saber, do poder, do ser, do ver) ainda ecoa graus de exclusão similar àqueles produzidos no colonialismo. Faz-se também necessária a compreensão descolonial de gênero, negligenciada nas frentes de investigação da colonialidade, para promover um olhar mais integrador, imperativo e urgente no processo de descolonização do arquivo colonial estudado. 


\title{
CAMINHOS POSSÍVEIS PARA UMA DESCOLONIZAÇÃO DA FOTOGRAFIA COLONIAL
}

\author{
A revisão da Constituição Política da República Portuguesa em 1951 aconteceu após \\ - 1 pressão do movimento anticolonialista na esteira do fim da Segunda Guerra Mundial.
} Para escapar das pressões externas, o termo "colônia" deu lugar a "províncias ultramarinas", junto com a ideia de "unidade da nação pluricontinental portuguesa". Naquele momento, Gilberto Freyre, a convite do ministro do Ultramar Sarmento Rodrigues, visitou Portugal para apresentar as ideias do luso-tropicalismo com os olhos de "homem intelectual" que defendia a "fantástica" adaptação do português aos trópicos. Esse pensamento foi de grande utilidade para o fortalecimento da ideia de "unidade da nação pluricontinental portuguesa". O Estado Novo português, portanto, apropriou-se de algumas "máximas luso-tropicalistas, para se defender das pressões da comunidade internacional, sobretudo no quadro da ONU [...], mas também em campanhas de propaganda no país e no exterior" (Castelo, 2013).

Nesse contexto histórico-político, as imagens foram produzidas aos milhares: era preciso ver para dominar. A fotografia, como já afirmou Ariella Azoulay (2019), é uma tecnologia que permitiu e permite a extração de riqueza visual de diversos lugares. Essa riqueza (não só material como também cultural) está atualmente confinada em arquivos, bancos de imagens e coleções privadas. A imagem, assim, atua em conformidade com as práticas imperialistas de exploração da terra e de pessoas com a classificação conforme a cor da pele.

As tentativas de realização de descolonização de um arquivo colonial são complexas e apresentam falhas. Um caso citado por Azoulay, em um ensaio ${ }^{5}$, faz menção ao caso dos daguerreótipos produzidos por Louis Agassiz de dois ex-escravos americanos, Renty e Delia, localizados no acervo da Universidade de Harvard. A tataraneta de Renty, Tamara Lanier, solicitou a devolução por vias jurídicas das imagens armazenadas e tem apoio até dos descendentes de Agassiz. Essas imagens seguiam os interesses científicos e políticos da Universidade e do próprio cientista, pois serviram como argumento racialista para apoiar a escravidão nos Estados Unidos. Entretanto, o processo ainda não foi finalizado, mas essas fotografias continuam a lembrar aos descendentes de Renty e Delia a humilhação e sofrimento existentes em um passado não tão distante.

Um exemplo de descolonização de imagens produzidas durante o colonialismo português pode ser visto no trabalho de Filipa César, no filme The Embassy $(2011)^{6}$. Nele, um álbum colonial, forma muito comum de apresentar as narrativas das missões coloniais na África, expressa códigos de representação colonial em Guiné-Bissau entre 1940 e 1950. 0 álbum, com o rigor documental que sequencia as imagens em capítulos com paisagens, pessoas e 
arquitetura, é interpretado pelo arquivista Armando Lona, de Guiné-Bissau, de acordo com sua cultura e vivência no local. A voz, antes calada pelo colonialismo, é dada àquele que tem seu povo representado, na tentativa de colaborar com a desconstrução do discurso colonial expresso nas imagens.

As imagens analisadas foram produzidas no colonialismo histórico, ou seja, num período que tinha a finalidade de extração dos recursos naturais por meio da violência política-militar do colonizador em outras jurisdições territoriais. Entretanto, o seu fim não eliminou a presença de outros mecanismos de poder que garantem a desapropriação de povos (Quijano, 2009). $O$ neocolonialismo do final do século XIX à metade do século XX, marca do Estado Novo português, não foi suficiente para a emancipação política, econômica e cultural dos países da África e nem da Ásia. Por isso, a finalidade deste trabalho é a de refletir sobre e encontrar espaços para a descolonização de fotografias produzidas no período colonial histórico, mas que ainda assombram o presente com a sua presença em arquivos e museus. Nesse contexto, seguimos uma perspectiva não imperial, compreendendo inicialmente que falar sobre colonialismo não é o mesmo que falar sobre colonialidade:

Não se trata de uma forma decorrente nem antecedente da modernidade. Colonialidade e modernidade constituem duas faces de uma mesma moeda. Da mesma maneira que a revolução industrial europeia foi possível graças às formas coercivas de trabalho na periferia, as novas identidades, direitos, leis e instituições da modernidade, de que são exemplos o Estado-nação, a cidadania e a democracia, formaram-se durante um processo de interação colonial, e também de dominação/exploração, com povos não ocidentais. (Grosfoguel, 2002: 126).

A distinção entre "colonialismo" e "colonialidade", portanto, reside no fato de que a colonialidade compreende a continuidade das formas de dominação colonial. Há várias maneiras de exercer a colonialidade. A "colonialidade de poder" refere-se à relação de conexão entre as formas de exploração e dominação modernas e o processo europeu colonial (Quijano). A "colonialidade do saber" reflete sobre a propagação de regimes de pensamento hegemônicos (Mignolo). A "colonialidade do ser" examina a experiência vivida de colonização e os impactos na linguagem e visão de mundo dos povos colonizados (Maldonato-Torres). Também há a "colonialidade do ver", que se refere aos registos visuais etnográficos coloniais e à produção de imagens reducionistas, estereotipadas e humilhantes das populações nativas, seus hábitos, cultura e espaços de vivência (Barriendos).

Na perspectiva da "colonialidade do ver", podemos constatar que o contexto da produção das imagens na Antropologia Física não deixa margem para pensá-las enquanto produto de tecnologias neutras. Esses registos localizados historicamente e geograficamente eram e continuam sendo representações que qualificam o Outro e determinam códigos 
que demarcam a exclusão de corpos. Sabemos que os meios de reprodução, arquivamento e transmissão foram modificados e amplificados, entretanto a hierarquização de territórios e grupos sociais ainda hoje se apresenta de modo binário, para representar em categorias o Eu em contraposição ao Outro. Apesar dos avanços nessas diferentes frentes de estudo da colonialidade, três áreas importantes foram negligenciadas: as relações de gênero; a apropriação da natureza e do meio ambiente; e a construção de imaginários econômicos que sirvam para sustentar as lutas contra o neoliberalismo (Escobar, 2003). Dessa forma, iremos traçar dois caminhos possíveis para a descolonização das imagens fotográficas coIoniais: as reflexões em torno da questão de poder dos arquivos e das relações de gênero expressas na fotografia.

\section{OS ARQUIVOS COLONIAIS E A FOTOGRAFIA}

riella Azoulay (2019) lembra-nos que a fotografia foi produzida no período colonial
sobáticas, estruturas e regimes imperiais de exploração que já eram preexistentes ao seu invento. Por isso, devemos evitar nos relacionar com a fotografia como se ela tivesse uma história separada da "invenção" do dispositivo no século XIX. A desconsideração dessa história de extração significa ignorar a forma como a fotografia acelerou e intensificou o processo de acumulação de riqueza (especialmente riqueza visual), trabalho e recursos de pessoas na África, Índia e Oriente Médio.

A fotografia, enquanto objeto, surge como lembrança de "um lugar" em uma sociedade branca e europeia. Por isso, quando essas imagens fazem parte de um arquivo colonial, o passado não é armazenado, mas fabricado, separando as pessoas em categorias imperiais para tornar-se objetos a servir como base de estudos acadêmicos coloniais. Os povos colonizados e escravizados não tinham o direito de se pronunciar, de modo que lhes era negado 0 direito de recusa à participação do evento fotográfico, sendo portanto esse o princípio extrativo sobre o qual a fotografia foi institucionalizada.

Os arquivos, entretanto, são essenciais para a investigação no âmbito das ciências sociais e humanas. Mas, como "não há arquivo sem exterior" (Derrida, 2001: 22), faz-se necessário ter a preocupação com a forma como têm sido produzidos e catalogados os registos, pois eles podem interferir na memória coletiva de determinada comunidade. A necessidade de discussão e problematização dos arquivos surge porque eles estão sempre vinculados ao poder, como afirmou Derrida (2001: 16), visto que este último determina "a participação e o acesso ao arquivo, à sua constituição e à sua interpretação". Desse modo, o surgimento dos arquivos tem conexão com o caráter político que os atravessa: "Para serem assim guardados, [...] eram necessários ao mesmo tempo um guardião e uma localização. [...] Foi assim, nesta 
domiciliação, nesta obtenção consensual de domicílio, que os arquivos nasceram" (Derrida, 2001: 13).

Compreende-se, portanto, que as fotografias coloniais presentes em arquivos têm conexão com o caráter político que as atravessa: reproduzem a violência do colonialismo e da escravidão por meio da sua circulação, propriedade e formas de exibição. Por isso, segundo Azoulay, desaprender o imperialismo significa desnaturalizar os documentos e práticas de documentação. Seguindo esse preceito, para que a fotografia dos arquivos coloniais desempenhe um papel de reparação, devem ser renegados os direitos exclusivos de guarda dessas fotografias. Por terem sido extraídas contra a vontade dos fotografados, elas devem ser acessadas livremente para que sejam catalogadas e arquivadas com a participação dos familiares ou da comunidade daqueles que foram retratados. Só assim a academia, instituição que propagou a Antropologia Física e construiu arquivos coloniais durante o neocolonialismo português, poderia participar ativamente da reparação com os povos africanos.

\section{RELAÇÕES DE GÊNERO NAS FOTOGRAFIAS COLONIAIS}

$\mathrm{O}$ s investigadores, médicos, cientistas e viajantes das missões antropológicas estavam sempre a selecionar e fotografar mulheres como "animais no sentido de seres 'sem gênero', marcadas sexualmente como fêmeas, mas sem características da feminilidade" (Lugones, 2014: 43). Essas mulheres não são vistas como mães e esposas que exercem os papéis das mulheres brancas numa sociedade patriarcal. A presença da imagem sexualizada das muIheres de continentes desconhecidos em arquivos coloniais não é novidade, visto que sempre fez parte das histórias dos viajantes:

Por séculos, os continentes desconhecidos - África, as Américas, Ásia — foram imaginados eroticamente pela erudição europeia como libidinosamente eróticos. As histórias de viajantes estavam repletas de visões da sexualidade monstruosa das terras distantes onde, como contavam as lendas, os homens tinham pênis gigantes e as mulheres se casavam com macacos, os peitos dos rapazes afeminados vertiam leite e os das mulheres militarizadas eram cortados por elas mesmas [...] Nessa tradição pornô-tropical, as mulheres apareciam como o epítome da aberração e dos excessos sexuais. 0 folclore as concebeu, ainda mais que aos homens, como entregues a uma venérea lascividade, tão promíscua que beirava o bestial. (McClintock, 1995: 22).

Maria Lugones (2014), filósofa feminista argentina, foi a responsável por inserir a categoria de gênero no pensamento descolonial. Para ela, o gênero surge quando o discurso colonial promove a dicotomia fundadora da classificação de indivíduos em humanos e não 
humanos. Nesse contexto, a mulher negra não se encaixava nem em negro (não humano) nem em mulher (humano): surge como uma intersecção desses dois caminhos e que sofre dupla subjugação (Lugones, 2014: 936).

Nas fotografias produzidas por António Marques de Almeida Júnior nas missões antropológicas de Angola (1955) e São Tomé e Príncipe (1954), pode-se notar que as mulheres examinadas e negras não são representadas da mesma forma que as mulheres brancas, aquelas que são parte da família nuclear prezada pelo colonialismo. A mulher negra, sem nome nos registos antropológicos, surge como objeto exótico de desejo que serve para alimentar a visão libidinosa, enquanto a mulher europeia/portuguesa surge, nas fotografias das missões, em ligações de parentesco com os homens da missão (filha, esposa), além de estarem representadas com o nome completo e sem a exposição de seus corpos (Figuras 10A e 10B).

0 sistema de gênero colonial, de acordo com Lugones, consolidou-se com "o avanço do(s) projeto(s) colonial(ais) da Europa. E começa a tomar forma durante o período das aventuras coloniais da Espanha e de Portugal e se consolida na modernidade tardia" (Lugones, 2014: 103). Para a filósofa nigeriana Oyèrónké Oyěwùmí, por exemplo, o sistema de gênero que foi
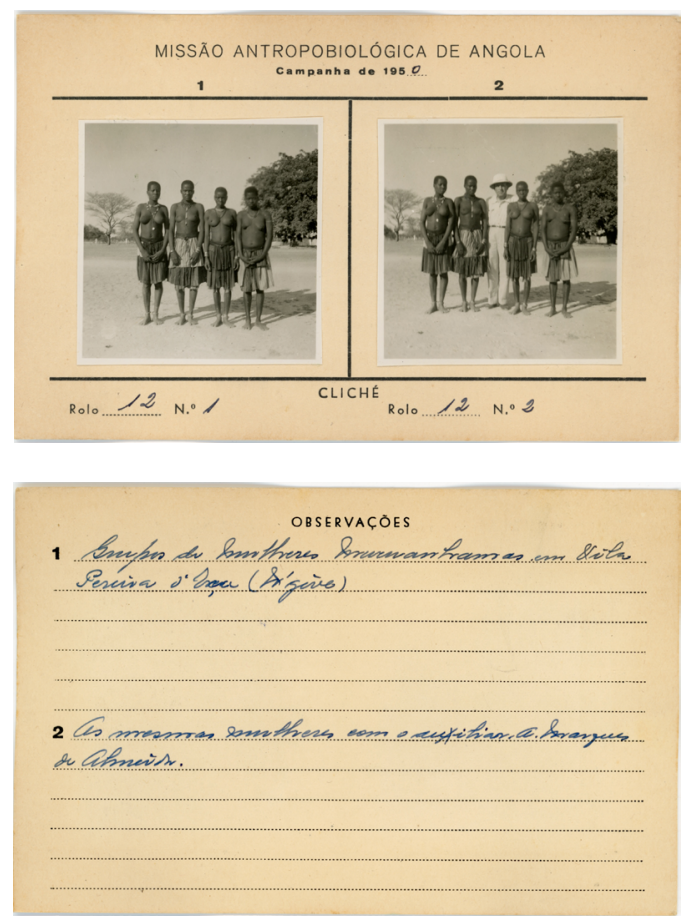

Figura $10(\mathrm{~A}, \mathrm{~B})$ - Ficha antropométrica indicando "mulheres mucuanhamas" e António Marques de Almeida com sua roupa branca (1950).

Fonte: Universidade de Lisboa/Instituto de Investigação Científica Tropical. 
imposto à sociedade lorubá (Nigéria) foi opressivo e fez mais que transformar a organização da produção pré-colonial, pois o sistema europeu incluía a subordinação da fêmea em todos os aspectos da vida. Isso porque a categoria "esposa" tem raízes na família nuclear e essa identidade é determinante, fazendo com que a definição de mulher se torne também a de esposa. Segundo Oyěwùmí, a "categoria fundamental da diferença, que aparece como universal e a partir dos limites da família nuclear, é o gênero" (Oyěwùmí, 2004: 11) (Figuras 11A e 11B).

Importante repensar as relações de gênero tendo como base o saber que se situa na interseccionalidade (Crenshaw, 1989), para tratar da existência das camadas de desigualdade (raça, etnia, gênero etc.). Olhar para esses espaços interseccionais, portanto, permite a desconstrução de padrões raciais coloniais e a escuta das vozes que foram acrescentadas à bibliografia dos estudos da colonialidade.
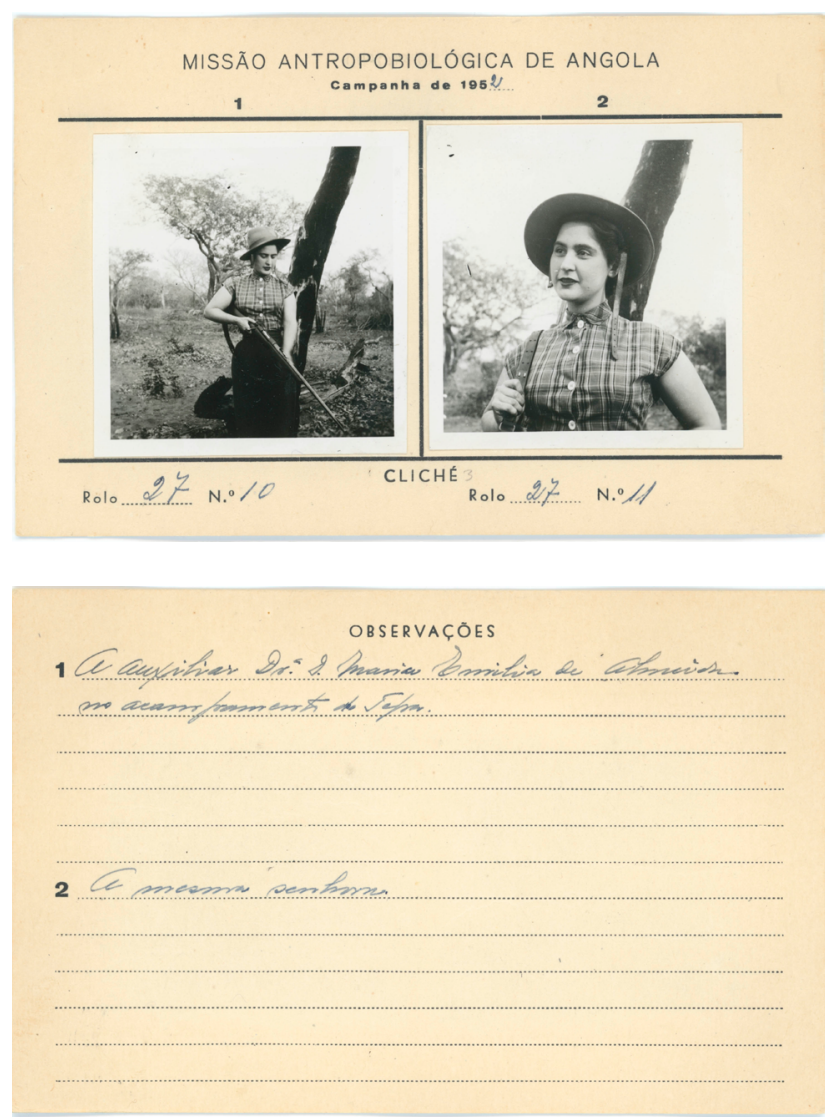

Figura $11(\mathrm{~A}, \mathrm{~B})$ - Mulher europeia nas missões: Doutora Maria Emília de Almeida, "senhora" e filha do chefe da Missão Antropobiológica de Angola.

Fonte: Universidade de Lisboa/Instituto de Investigação Científica Tropical. 
Dessa forma, compreende-se também a intersecção de raça, gênero e trabalho nas imagens apresentadas. Os africanos e africanas são apresentados sempre como objetos da imagem, sendo, quantitativamente, as mulheres negras mais presentes nas imagens que os homens negros. Por outro lado, a mulher branca é apresentada como membro da equipe, como investigadora, e sua imagem com uma arma ou, por vezes, brincando com animais selvagens da localidade, mostra também o seu poder e hierarquia em relação às mulheres africanas, que serviam para apresentar seus corpos a fim de serem transformados em objetos de desejo e em números/dados antropológicos.

\section{CONSIDERAÇÕES FINAIS}

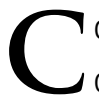
onforme foi constatado por Aníbal Quijano (2009), com o pensamento da "colonialidade de poder", ainda vivemos num mundo colonial e é preciso, por isso, pensar de forma ampla sobre as relações coloniais que ainda permeiam o mundo contemporâneo, na tentativa de contribuir para a sua descolonização. No intuito de encontrar alternativas para além do pensamento fundamentalista eurocêntrico foi proposta, assim, a análise dos arquivos fotográficos coloniais e das relações de gênero, que não foram, estas últimas, abrangidas pelos pensadores do paradigma modernidade-colonialidade. 0 pensamento de Derrida e Azoulay contribuiu para a constatação de que o arquivo só poderá ser desprovido do poder colonial se for aberto à consulta e às informações das comunidades e familiares dos retratados, além de sujeito à restituição de arquivos aos que necessitem os bens que lhe foram extraídos. Por fim, esta reflexão sobre fotografias coloniais portuguesas surge como uma tentativa descolonizar arquivos que ainda constroem as memórias dos povos com passado colonial.

Conflitos de interesse: nada a declarar.

Fonte de financiamento: Projeto Photo Impulse.

\section{NOTAS}

1 Toda a documentação e produção fotográfica consultadas fazem parte do acervo do Instituto de Investigação Científica Tropical (IICT), no arquivo que funciona nas instalações do Arquivo Histórico Ultramarino em Lisboa (AHU) (Arquivo Científico Tropical - ACTD). Esses arquivos fotográficos e diários consultados, entretanto, não estão disponíveis para consulta on-line ou do público. 
2 Muitas vezes aqueles trabalhadores se recusavam a participar das investigações e não compareciam ao local que os donos das roças definiam para a observação de seus caracteres físicos, as fotografias e a coleta de sangue, segundo os relatos encontrados no diário do fotógrafo Almeida Jr. 3 "A cor [...] permite reproduzir a realidade da forma mais fiel possível. [...] Em certo sentido, a foto colorida se apresenta como uma abordagem mais 'neutra' diante do mundo como um retrato mais 'objetivo' da realidade. Elas reproduzem a aparência das coisas da forma mais exata, ao passo que as imagens em preto e branco produzem um efeito de estranhamento que visa destacar a essência do real" (Puls, 2016).

4 Compreende-se, entretanto, que as imagens dos cartões eram produzidas em preto e branco talvez por ser um modo mais rápido e fácil de revelação fotográfica no local onde eram realizadas as fotografias nas missões portuguesas.

5 Cf. disponível em: <https://eu.usatoday.com/story/news/nation/2019/06/20/agassiz-descendants-urge-harvard-give-up-renty-delia-slave-photos/1508475001/>. Acesso em: 28 nov. 2020.

6 The Embassy, 2011. Disponível em: <https://vimeo.com/199996126>. Acesso em: 28 nov. 2020.

\section{REFERÊNCIAS BIBLIOGRÁFICAS}

ARQUIVO HISTÓRICO ULTRAMARINO. Angola, 1954. Lisboa: AHU, 1954. [António Almeida Júnior, Diário de Campo].

AZOULAY, A. Potential history: unlearning imperialism. London: Verso, 2019.

BERTHET, M. A. Reflections on roças in São Tomé and Príncipe. Estudos Históricos, Rio de Janeiro, v. 25, n. 50, p. 331-351, jul./dez. 2012. https://dx.doi.org/10.1590/S0103-21862012000200004.

CASTELO, C. O luso-tropicalismo e o colonialismo português tardio. Revista Buala, Lisboa, 5 mar. 2013. Disponível em: <https://www.buala.org/pt/a-ler/o-luso-tropicalismo-e-o-colonialismo-portugues-tardio>. Acesso em: 28 nov. 2020.

CORREIA, M. O Instituto de Antropologia da Universidade do Porto e a investigação científica colonial. In: CONGRESSO NACIONAL DE ANTROPOLOGIA COLONIAL, 1., 1934, Porto. Anais [...]. Porto: Imprensa Portuguesa, 22 a 26 set. 1934. [Edição da I Exposição Colonial Portuguesa].

CORREIA, M. Factores degenerativos na população portuguesa e seu combate. In: CONGRESSO NACIONAL DE CIÊNCIAS DA POPULAÇÃO, 1940, Porto. Actas [...]. Porto: Imprensa Portuguesa, 1940, v. 1.

CORREIA, M. Raças do Império. Porto: Portucalense Editora, 1943.

CRENSHAW, K. Demarginalizing the intersection of race and sex: a black feminist critique of antidiscrimination doctrine, feminist. In: FEMINISM IN THE LAW: theory, practice, and criticism. Chicago: University of Chicago Legal Forum, 1989. p. 139-167. 
DERRIDA, J. Mal de arquivo. Tradução de Claudia de Moraes Rego. Rio de Janeiro: Relume Dumará, 2001.

EDWARDS, E. Photographic "types": the pursuit of method. Visual Anthropology, United Kingdom, v. 3, n. 2-3, p. 235-258, 1990. https://doi.org/10.1080/08949468.1990.9966534.

EDWARDS, E. Material beings: objecthood and ethnographic photographs. VisualStudies, United Kingdom, v. 17, n. 1, p. 67-75, 2002. Disponível em: <https://www.tandfonline.com/doi/abs/10.1080/14725860220137336>. Acesso em: 28 nov. 2020. https://doi.org/10.1080/14725860220137336.

ESCOBAR, A. Mundos y conocimientos de otro modo: el programa de investigación de modernidad/ colonialidad latinoamericano. Tabula Rasa, Bogotá, n. 1, p. 51-86, enero/dic. 2003.

GROSFOGUEL, R. Colonial difference, geopolitics of knowledge and Global coloniality in the modern/colonial capitalist world-system. Review, Albany, v. 25, n. 3, p. 203-224, 2002.

HALL, S. The work of representation. In: HALL, S. Representation: cultural representation and signifying practices. London: Sage, 1996. p. 13-74.

LUGONES, M. Rumo a um feminismo descolonial. Tradução de Juliana Watson e Tatiana Nascimento. Revista Estudos Feministas, Florianópolis, v. 22, n. 3, p. 935-952, set./dez. 2014. https://doi.org/10.1590/S0104$026 \times 2014000300013$.

MATOS, P. F. A fotografia na obra de Mendes Correia (1888-1960): modos de representar, diferenciar e classificar da "Antropologia colonial". In: VICENTE, F. L. (org.). O império da visão: fotografia no contexto colonial português (1860-1960). Lisboa: Edições 70, 2014.

McCLINTOCK, A. Imperial leather: race, gender, and sexuality in the colonial contest. New York: Routledge, 1995.

OYĚWÙMÍ, O. The invention of women: making an African sense of Western gender discourses. Minneapolis: University of Minnesota Press, 1997.

PEREIRA, R. M. Raça, sangue, robustez. Os paradigmas da Antropologia Física colonial portuguesa. Cadernos de Estudos Africanos, Lisboa, n. 7-8, p. 209-241, 2005. https://doi.org/10.4000/cea.1363.

PINNEY, C. The parallel histories of anthropology and photography. In: EDWARDS, E. (ed.). Photography and Anthropology 1860-1920. New Haven: Yale Universtity Press, 1992. p. 74-95.

POLONI, R. A ciência vivida: a arqueologia e as missões antropológicas do oficial à prática. In: ATAS DO COLÓQUIO TIMOR: MISSÕES CIENTÍFICAS E ANTROPOLOGIA COLONIAL. Lisboa: ICT/AHU, 24-25 maio 2011. Disponível em: <http://www.historyanthropologytimor.org/wp-content/uploads/2012/01/17-POLONI_ Rita.pdf>. Acesso em: 28 nov. 2020.

PULS, M. Cor ou preto e branco? Razões de uma escolha. Revista Zum, 11 mar. 2016. Disponível em: <https:// revistazum.com.br/radar/cor-ou-pb/>. Acesso em: 28 nov. 2020.

QUIJANO, A. Colonialidade do poder e classificação social. In: SANTOS, B.; MENESES, M. P. (orgs.). Epistemologias do Sul. Coimbra: Edições Almedina: 2009.

ESTUDOS ULTRAMARINOS - REVISTA DO INSTITUTO SUPERIOR de Estudos UItramarinos, Lisboa, v. VI, 1956. Missão Antropológica de Angola (Campanha de 1955). [Exemplar não catalogado e não disponível para acesso público). 
ROQUE, A. C. Missão Antropológica de Moçambique. A fotografia como instrumento de trabalho e propaganda. In: VICENTE, F. L. (ed.). O império da visão. Fotografia em contexto colonial 1860-1960. Lisboa: Edições 70, 2014. p. 107-115.

SEIBERT, G. Colonialismo em São Tomé e Príncipe: hierarquização, classificação e segregação da vida social. Anuário Antropológico, II, p. 99-120, 2015. Disponível em: <http://journals.openedition.org/ aa/1411 >. Acesso em: 28 nov. 2020. https://doi.org/10.4000/aa.1411.

TAGG, J. El peso de la representación. Barcelona: Gustavo Gili, 2005. 